\title{
Comparison between Right and Left Ventricular Myocardia during the Human Fetal Period. Stereological Evaluation
}

\author{
Ricardo Xavier-Vidal, Kalil Madi \\ Rio de Janeiro, RJ - Brazil
}

\begin{abstract}
Purpose - To develop a stereological comparison between right $(R V)$ and left ventricle $(L V)$ myocardium during the third human gestational trimester.
\end{abstract}

Methods - Five human fetal hearts of the third trimester provided representative samples of $5 R V$ myocardium and 4 LV myocardium. The material was fixed in $10 \%$ buffered formaldehyde, and processed through routine methods. Fifteen microscopic fields were randomly chosen and counted in each ventricular myocardium using an "M-42" test system. The following stereological parameters were assessed: $V v(\%), L v\left(\mu m^{2}\right), S v\left(\mu m^{2} / \mu m^{3}\right)$, $V p\left(\mu m^{3}\right), N v\left(1 / \mathrm{mm}^{3}\right)$ and total $N$.

Results - No significant difference between the stereological parameters of the myocardial structures assessed was evidenced, when comparing $R V$ and $L V$.

Conclusion - Right and left human ventricular myocardium are very similar during the fetal period at least in regard to their structural aspects.

Key words: cardiac development, fetus, morphology, morphometry, stereology, biometry
Hospital Universitário Clementino Fraga Filho - UFRJ - Rio de Janeiro Mailing address: Prof. Ricardo Xavier-Vidal - ASSOCIAÇÃO XAVIER-VIDAL para Direitos Humanos, Ciência, Tecnologia e Desenvolvimento, Caixa Postal 100.768, Niterói, RJ, Brazil, CEP 24001-970.

E-mail: rxavier-vidal@interclub.com.br
Although reasonable knowledge about intrauterine cardiovascular development currently exists, certain aspects of this process are still causing much scientific discussion. Some details of intrauterine cardiovascular development in the human and other species have been clarified recently ${ }^{1-10}$, but these still have yet to be confirmed. It is also important to assess interspecific differences to avoid rough interpretational errors in the results obtained ${ }^{9-11}$. Even though the idea that differences exist between RV and LV myocardial structures in the same individual during development is controversial, few studies have focused on this subject ${ }^{12,13}$.

A significant benefit of the cardiovascular assessment of anatomicopathological studies is that the cause of death can be more rapidly clarified during the perinatal period when death is due to gross malformations. However, difficulties increase when the events are mainly related to microscopic structures ${ }^{14}$. For example, even though myocardial changes during sudden infant death have been described, only incipient knowledge in this area is available ${ }^{14,15}$. In industrialized countries, sudden death accounts for 300,000 to 400,000 deaths per year, of which $80 \%$ to $90 \%$ are due to coronary heart diseases. It is known that $50 \%$ of the deaths due to coronary heart disease are sudden, and congenital anomalies of the coronary arteries are a very important cause of such deaths ${ }^{16}$. These coronary artery anomalies may lead to changes in the capillary bed and in the general structure of the myocardium, which may be significant in perinatal mortality. For example, even though sudden cardiopulmonary arrest in children is very rare (with not always very successful results of resuscitation) and ventricular fibrillation occurs in less than $10 \%$ during that event, these occurrences are more common in children with congenital heart disease ${ }^{17}$. Cardiopulmonary arrest associated or not with congenital anomalies leads, in many cases, to some type of cardiac alteration, which may cause some degree of structural reorganization of the myocardium. Sudden death following myocardial infarction is usually due to abnormalities in the cellular electrophysio$\operatorname{logy}$ caused by ischemia. However, sudden death seems to be related to the postinfarction scarring process, because 
the subsequent and persistent emerging arrhythmogenic potential is not primarily dependent on the effect of ischemia on cellular electrophysiology, but on the alteration of the stability of the injured and recovering tissular structure ${ }^{18}$. Therefore, it is of scientific importance to evaluate the structural organization of the myocardial tissue, defining a normal standard because infants with abnormal hearts and/or succumbing to sudden death seem to have a smaller number of nuclei of the myocytes $(\mathrm{Nv})$ per unit of volume in the myocardium than normal ${ }^{13}$. Another important tissular alteration in cases of sudden death syndrome in infants is the occurrence of reactive fibrosis (interstitial fibrosis) ${ }^{15}$, where the involvement of the nitric oxide debit is possible ${ }^{19}$. This fibrosis can also be evaluated by the stereological method.

The objective of this study was to develop a stereological comparison between the normal myocardial structure of the RV and LV during the third human gestational trimester.

\section{Methods}

Five human fetal hearts of the third gestational trimester provided representative samples of five RV myocardia and four LV myocardia obtained from the free cardiac wall. The fetuses were obtained from spontaneous abortions. Maternal age and sexes of the fetuses could not be considered for the approach here developed. The fetuses were dated according to the length of the largest foot ${ }^{20-23}$. The material was fixed in buffered $10 \%$ formaldehyde, processed according to routine methods, sliced into $5 \mu \mathrm{m}$ fragments, and stained with hematoxylin-eosin.

Holmes effect, the overestimation error ${ }^{24}$, is considered nonexistent with the use of the disector method ${ }^{25-29}$. Fifteen microscopic fields randomly chosen in each right or left ventricular myocardium were counted for stereological evaluation. The countings were performed with an "M-42" test system mounted in a Nikon CFW eyepiece (10X) using immersion objective (100X). The numbers of structures and points and the intersections overlapping the structures considered were counted. Statistical analysis was performed using Student's $t$-test. A p $<0.05$ was considered significant ${ }^{30-31}$. The stereological parameters considered were as follows ${ }^{25,27,28-32}$ :

$\mathrm{Vv} \%$ - volumetric density ${ }^{32}$.

$$
\mathrm{Vv} \%=\frac{\mathrm{P}_{\mathrm{P}}}{\mathrm{P}_{\mathrm{T}}} * 100
$$

Where: $\mathrm{PP}=$ counted points, $\mathrm{PT}=$ total of points of the test-system;

$\mathrm{Sv}\left(\mu \mathrm{m}^{2} / \mu \mathrm{m}^{3}\right)-$ surface density ${ }^{32} . \mathrm{Sv}=2 \times \mathrm{I}_{1}$, where $\mathrm{I}_{1}=$ intersections of the structures with the test lines;

$\mathrm{Nv}\left(1 / \mathrm{mm}^{3}\right)-$ numerical density ${ }^{25-27}$.

$$
\mathrm{Nv}=\frac{\Sigma \mathrm{Q}^{-}}{\Sigma \mathrm{V}_{(\mathrm{dis})}}
$$

Where: $\mathrm{V}($ dis $)=\mathrm{t} \times \mathrm{At} ; \mathrm{V}($ dis $)=$ volume of the disector; $\mathrm{t}=$ thickness of the microtome section; $\mathrm{At}=$ area of the test; $\Sigma$ Q- = sum of the structures counted in one of the faces of the histological section; $\Sigma \mathrm{V}($ dis $)=$ sum of the volume of the disector;

$\mathrm{Vp}\left(\mu \mathrm{m}^{3}\right)$ - ponderal volume ${ }^{28} . \mathrm{Vp}=\mathrm{Vv} / \mathrm{Nv}$;

$\mathrm{Lv}\left(\mu \mathrm{m}^{2}\right)-$ density of length ${ }^{32} ; \mathrm{Lv}=2 \times \mathrm{Qa}, \mathrm{Qa}\left(\mu \mathrm{m}^{-2}\right)-$ density of profiles in the area of the test.

$$
\mathrm{Qa}=\frac{\Sigma \text { perfis }}{\text { At }}
$$

Where: $\Sigma$ profiles $=$ number of structures in the area of the test; At = area of the test;

$\mathrm{N}$ - total number of structures in the organ ${ }^{27} . \mathrm{N}=\mathrm{Nv}$ $\left(\mathrm{mm}^{3}\right)$ x cardiac weight $(\mathrm{mg})$.

\section{Results}

Our results showed no significant difference between the stereological parameters of the myocardial structures evaluated (table I and figures 1-3). We performed a myocardial quantitative evaluation for myocytes and their respective nuclei. The values not included in table I have already been evaluated in former articles and are commented on the discussion.

\section{Discussion}

Stereological and allometric quantitative studies of the human fetal myocardium recently developed are scant ${ }^{33-38}$. Comparison between human and animal data is important to avoid interpretational distortions that may happen in experimental studies ${ }^{9,11}$. Morphometrical models are important to determine physiological and morbid variations that occur in biological tissues ${ }^{26,27,39-43}$.

The degree of proliferation/hypertrophy of the cardiomyocytes during the perinatal period is still controversial $^{5,44,45}$. The degree of myocardial regeneration during this period varies in a directly proportional manner with the potential of cellular proliferation ${ }^{5}$. It was suggested that differences in the capillary bed could cause the difference in the pattern of growth of RV and LV ${ }^{12}$. Other authors ${ }^{13}$, however, have identified a similar pattern of growth of the $\mathrm{Nv}$ of myocytes (per volume unit in the myocardium), in both ventricles, during the perinatal period. Our results showed no significant differences between the stereological parameters of the blood vessels, when the RV and LV were compared. However, an increase in the number of fields to be counted - and an increase in the number of hearts taken into account - may provide significant differences in the evaluation of myocardial revascularization. A reasonable number of fields to be counted for the evaluation of myocytes is around 10 fields per ventricle; for blood vessels, however, the number of fields should be greater, around 142 fields per ventricular myocardium ${ }^{46,47}$. Another example occurs in the adult rat, whose consistent evaluation 


\begin{tabular}{|c|c|c|c|}
\hline & $\operatorname{LV}(n=4)$ & $\mathrm{RV}(\mathrm{n}=5)$ & $\mathrm{p}$ \\
\hline \multicolumn{4}{|l|}{$\mathrm{Vv}(\%)$} \\
\hline Myocytes & - & $64.64 / 1.76$ & - \\
\hline Connective tissue (bve) & - & $29.14 / 1.26$ & - \\
\hline Blood vessels & - & $6.22 / 0.81$ & - \\
\hline \multicolumn{4}{|l|}{$\mathrm{Vp}\left(\mu \mathrm{m}^{3}\right)$} \\
\hline Myocyte & $1366.45 / 63.30$ & $1203.03 / 58.58$ & $>0.05$ \\
\hline Nucleus & - & $174.06 / 45.63$ & - \\
\hline \multicolumn{4}{|l|}{$\operatorname{Sv}\left(1 / \mu m^{2}\right)$} \\
\hline Vessels & $1.63 \mathrm{E}-02 / 5.67 \mathrm{E}-03$ & $2.41 \mathrm{E}-02 / 5.58 \mathrm{E}-03$ & $>0.05$ \\
\hline \multicolumn{4}{|l|}{$\operatorname{Lv}\left(\mu \mathrm{m}^{2}\right)$} \\
\hline Vessels & $4.32 \mathrm{E}-04 / 1.53 \mathrm{E}-04$ & $5.40 \mathrm{E}-04 / 1.03 \mathrm{E}-04$ & $>0.05$ \\
\hline \multicolumn{4}{|l|}{$\mathrm{Nv}\left(1 / \mathrm{mm}^{3}\right)$} \\
\hline Myocyte & $561028.21 / 42908.17$ & $547116.74 / 40675.67$ & $>0.05$ \\
\hline Nucleus & - & $399675.48 / 41712.1$ & - \\
\hline Vessels & $43156.02 / 15284.33$ & $54021.18 / 10321.14$ & $>0.05$ \\
\hline \multicolumn{4}{|c|}{ Total number of structures ("N") ( $\mathrm{n}=4$, both for $\mathrm{LV}$ and RV) } \\
\hline Myocyte & $1.50 \mathrm{E}+10 / 1.40 \mathrm{E}+09$ & $1.45 \mathrm{E}+10 / 1.97 \mathrm{E}+09$ & $<0.001$ \\
\hline
\end{tabular}

of myocardial blood vessels requires a much larger number of fields than the evaluation of myocytes and connective tissue ${ }^{43}$. In this case, the number of fields to be counted should be around 422 fields per ventricular myocardium ${ }^{46,47}$.

Studies of the myocyte nuclei are important, for example, for the identification of the orientation of the bundles of cardiomyocytes in the myocardium, which can be performed by means of the confocal scanning laser microscopy ${ }^{48}$. Disorganization in the orientation of the bundles of cardiomyocytes has been described in certain cardiomyopathies ${ }^{49-52}$. It is known that these diseases can affect human beings, even the very young ${ }^{14}$. The most emphatic difference between the myocardium of an infant and that of an adult is the diameter of myocytes, which is much smaller in the former. Yet in the infant, the nucleus is proportionally larger than in the adult cell. Another important characteristic is that, in the infant, both the endocardium and the epicardium are thinner, and the latter has less adipose tissue than the adult ${ }^{15}$.

In stereological analysis using the disector method,

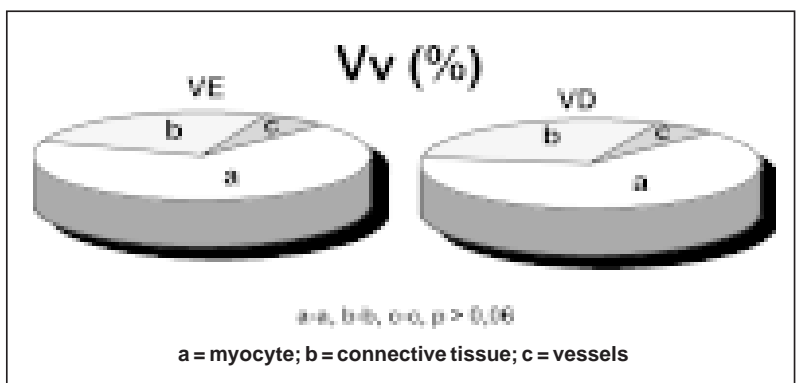

Fig. 1-Graphic comparing the volumetric density of cardiac myocytes, connective tissue and blood vessels of right and left ventricles. we verified a reduction in the $\mathrm{Nv}\left(1 / \mathrm{mm}^{3}\right)$ of the $\mathrm{LV}$ myocyte nuclei from 703,948 (EP=70490) to $397.304(\mathrm{EP}=27362)$, from the second to the third gestational trimester, respectively. The mean (second + third trimesters) was around $550,626 / \mathrm{mm}^{3}$. However, the total number of nuclei $(\mathrm{N})$ in the heart significantly increased from 2,101,152,700 (EP = 449634529) in the second trimester to $11,147,569,300(\mathrm{EP}=$ 2222847632) in the third trimester, which resulted from the increase in the heart volume throughout time $(\mathrm{p}<0.06$; Mann-Whitney Rank Sum Test). In human beings, Vv\% of the nucleus significantly decreases from the second to the third trimester during fetal development ${ }^{36}$. Components of

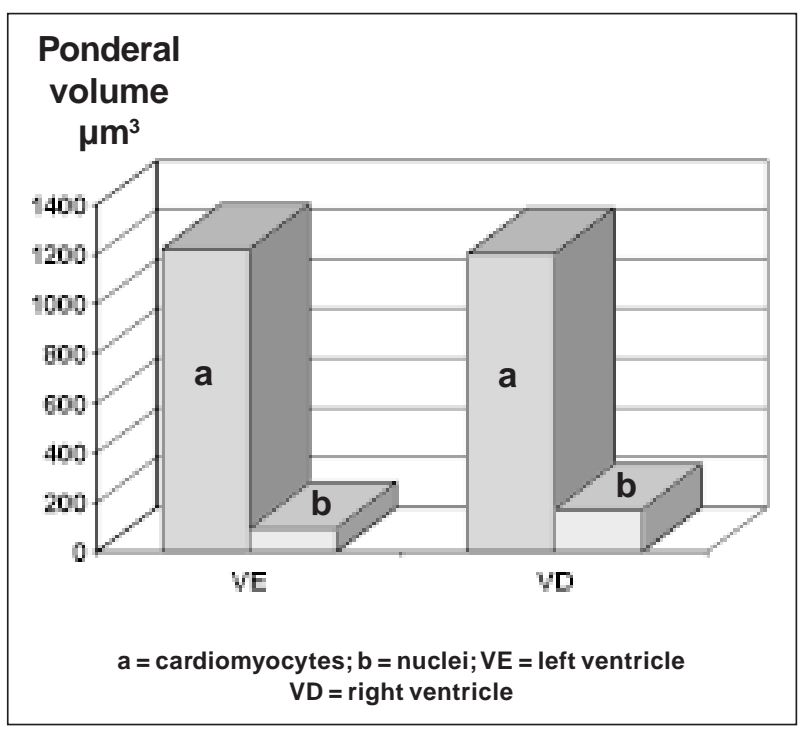

Fig. 2-Graphic comparing the ponderal volume of cardiac myocytes and their nucle of right and left ventricles. 


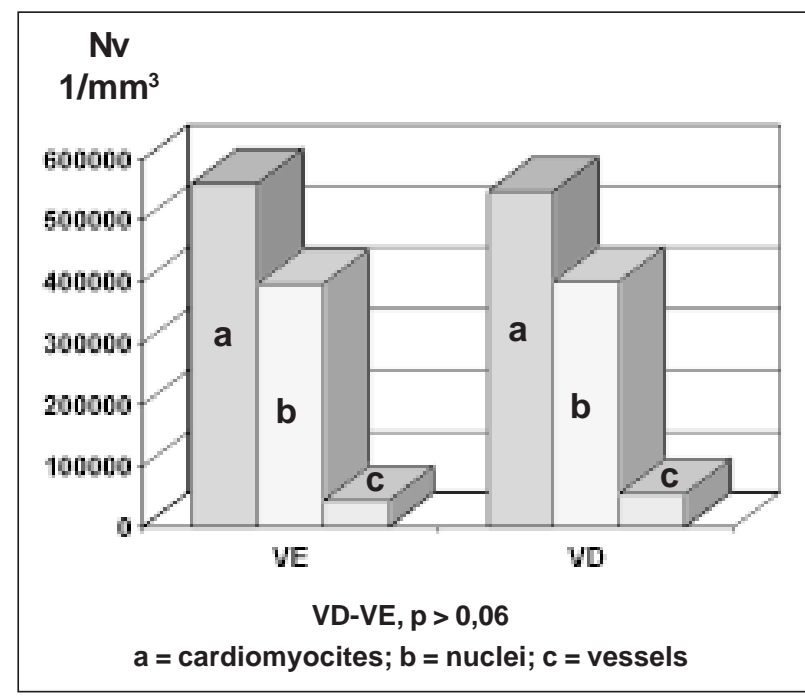

Fig. 3-Graphic comparing the numerical density of cardiomyocites (a), their nucle (b) and blood vessels (c) of right (VD) and left ventricles (VE).

the ventricular wall, such as myocytes, connective tissue and vessels, however, maintain a proportional relation from the second to the third gestational trimester ${ }^{33}$. In the rat, during the fetal and perinatal periods, heart growth results mainly from the increase in the number of myocardial cells, which ceases after approximately two weeks of age. After this period, the growth results from hypertrophy rather than an increase in the number of myocytes, which end up by ceasing their process of division ${ }^{1,53}$.

Volumetric density ( $\mathrm{Vv} \%$ ) relates to the proportion of structures evaluated in the organ or tissue studied ${ }^{32}$. In a previous article ${ }^{33}$ we reported that we identified in the $\mathrm{LV}$ in the third gestational trimester a $\mathrm{Vv} \%$ of myocytes, connective tissue (except for blood vessels), and blood vessels of 67.67, 25.94, and 6.39, respectively, while for the RV the values in the present study were $64.64,29.14$, and 6.22, respectively. Testing the samples, we did not identify any significant difference between the two ventricular walls $(p>0.05)$. In a former article ${ }^{36}$, assessing Nv nuclei and its volume ( $\mathrm{Vp}$ ) in $\mathrm{LV}$ during the third gestational trimester, we found the following values: $\mathrm{Nv}=397,304\left(1 / \mathrm{mm}^{3}\right)$ and $\mathrm{Vp}=97.66 \mu \mathrm{m}^{3}$. In the present study, the values of RV for $\mathrm{Nv}$ and $\mathrm{Vp}$ were, respectively, $399,675.48\left(1 / \mathrm{mm}^{3}\right)$ and $174.06 \mu \mathrm{m}^{3}$. Testing the samples, we did not identify significant differences between the two ventricular walls $(\mathrm{p}>0.05)$. The ponderal volume $(\mathrm{Vp})$ is the volume of the cell (or structure) indirectly obtained as described $(\mathrm{Vp}=\mathrm{Vv} / \mathrm{Nv})^{28}$. To obtain the direct volume, it is necessary to use the Cavalieri method (with serial or alternate sections), which is also a morphometric method ${ }^{47}$. The numerical density $(\mathrm{Nv})$ is the number of structures per a certain volume (for example, $\left.\mathrm{mm}^{3}\right)^{25-27}$. In the case, the number of cells is not always very close to the number of their nuclei in a certain volume. In the present study, while the number of myocytes in the RV is $547,116.74$, the Nv is 399,675.48; therefore, hypertrophy is clearly evident in a diseased heart when compared with a healthy heart. The larger the cells, the rarer it is to visualize the cell nuclei inside the counting grid. In the same way, it is more common to find more cardiomyocyte nuclei of human fetuses inside the counting grid than it is to find cardiomyocyte nuclei of adults.

Porter and Bankston ${ }^{3}$, studying fetuses of rats, found a mean $\mathrm{Vv} \%$ for cardiac myocytes of $85.6 \%$, for connective tissue (vessels excluded) of $2.8 \%$, and for vessels of $11.6 \%$. $\mathrm{Zak}^{45}$ and Weber ${ }^{54}$ estimate that the ventricular myocardial myocytes in the adult occupy $75 \%$ of the structural space, while the cardiac interstitium (intercellular substance including the vessels) occupies the remaining $25 \%$. Santos and Mandarim-de-Lacerda ${ }^{38}$, also developing a stereological study during the third gestational trimester, obtained results partially close to ours. The mean values found were: Vv\% of $77.8 \%$ for the cardiac myocytes and $22.2 \%$ for the interstitium. Nv of the cardiac myocytes (calculated based on the number of their nuclei) was $574,000 / \mathrm{mm}^{3}$. The volume of the myocyte was $1412.3 \mu \mathrm{m}^{3}$. The mean total " $\mathrm{N}$ " of myocytes per heart was $5.06 \mathrm{E}+09$.

The results of this study did not show a significant difference between any of the stereological parameters of the myocardial structures evaluated in the comparison of right and left ventricular myocardium. This suggests that, at least in regard to the structural question, human right and left ventricular myocardium are very similar during the fetal period. However, at least in the adult rat, there may be differences in regard to some biochemical details, such as, for example, the fact that RV tends to be notably more sensitive to injury due to systemic blockade of nitric oxide (LNAME model) than the LV. However, this greater intensity of damage may have occurred as a result of the greater demand for the LV during the hypertensive process in this model ${ }^{19}$.

Other stereological parameters here studied such as surface density $\left(\mathrm{Sv}, 1 / \mu \mathrm{m}^{2}\right)$ and density of length $\left(\mathrm{Lv}, \mu \mathrm{m}^{2}\right)$ were used only for blood vessels. The density of length $\left(\mathrm{Lv}, \mu \mathrm{m}^{2}\right)$ refers to the variation in the length of the evaluated structures. The surface density $\left(\mathrm{Sv}, 1 / \mu \mathrm{m}^{2}\right)$ relates to the variation in the surface of contact with the external medium and it is sensitive to the variation of the volume of the structure evaluated. Evaluation of cellular hypertrophy is a clear manner to understand the sensibility of the surface density. In a former study ${ }^{43}$, evaluating the hypertensive process and the cardiac hypertrophy through the systemic blockade of the nitric oxide (L-NAME model), the mean surface density $(\mathrm{Sv})$ of the healthy cardiac myocytes (control) was $0.152\left(1 / \mu \mathrm{m}^{2}\right)$, while in the hypertrophied cardiac myocytes, the increase in the mean volume was found as $30 \%$ with reduction in the mean surface density to 0.0812 $\left(1 / \mu \mathrm{m}^{2}\right)(\mathrm{p}<0.001)$.

Currently, the association between microscope and equipment, such as the confocal scanning laser microscope, that uses software to handle imaging, makes it possible to observe the deep planes of the tissues, either fixed or in vivo. These analyses use fine and precise focus on one single plane. These planes can be deepened in the tissue so that sequential images can be obtained along the structures. This 
way, it is possible to stipulate the depth of the focal plane of visibility as, for example, in 2 or $7 \mu$ m of depth, which makes the observations according to the disector ${ }^{55}$ method much easier. The focus on a single plane, as in the confocal device, nullifies the Holmes effect ${ }^{24}$. Analyses by tridimensional reconstruction are also possible in this type of device ${ }^{55}$. The confocal scanning laser microscope has a striking versatility, being useful either for studies of identification of structures of adhesion, such as gap junctions ${ }^{56}$ and the appearance of the adhesion molecules during the embryonic period ${ }^{57}$, or for the study of the orientation of bundles of muscle cells in the cardiac tissue ${ }^{55}$.

\section{Acknowledgements}

To the professors Drs. W.S. Costa, C.A. Mandarimde-Lacerda, Vera Aires, M. Costa-Neves, W.N. Viana, V.C. Villar, L.R. Mendes Barboza, M. Guimarães and Dempson Chilinque, for their incentive. Supported by CAPES, CNPq and CIC-HUCFF/UFRJ, AXV.

\section{References}

1. Zak R. Development and proliferative capacity of cardiac muscle cells. Circ Res 1974; 34-35(supl II): 17-25.

2. Gittenberger-de Groot AC. Elucidating coronary arterial anatomy or simplifying coronary arterial nomenclature. Int J Cardiol 1986; 12: 305-7

3 Porter GA, Bankston PW. Myocardial capillaries in the fetal and the neonatal rat: a morphometric Analysis of the Maturing Myocardial Capillary Bed. Am J Anat 1987; 179: 108-115.

4. Bogers AJJC, Gittenberger-de Groot AC, Dubbeldam JA, Huysmans HA. The inadequacy of existing theories on development of the proximal coronary arteries and their connections with the arterial trunks. Int J Cardiol 1988; 20: 117-23.

5. Bishop SP, Hine P. Cardiac muscle cytoplasmic and nuclear development during canine neonatal growth. In: Roy P (ed) - Recent advances in studies on cardiac structure and metabolism. Baltimore: University Press, 1975: 77-98.

6. Wenink ACf, Zevallos JC, Erkelens WG. Human developmental stages of atrioventricular septal defect. In: Clark EB, Takao A (eds) - Developmenta Cardiology: Morphogenesis and Function. New York: Futura, 1990: 593-603.

7. Kirby ML. Role of neural crest in structural and functional developement of heart. In: Clark EBM, Takao A (eds) - Developmental Cardiology: Morphogenesis and Function. New York: Futura Publishing, 1990.

8. Chien KR, Zhu H, Knowlton KU, et al. Transcriptional regulation during cardiac growth and development. Annu Rev Physiol 1993; 55: 77-95.

9. Xavier-Vidal R. Uma breve revisão sobre alguns aspectos do desenvolvimento embrionário do coração com especial referência às artérias coronárias. Arq Bras Cardiol 1997; 68: 305-9.

10. Knaapen MW, Vrolijk BC, Wenink AC. Ultrastructural changes of the myocardium in the embryonic rat heart. Anat Rec 1997; 248: 233-41.

11. Xavier-Vidal R, Cunha RC, Madi K. Quantitative study using semithin section of the rat fetal myocardium. Rev Chil Anat 1997; 15: 209-16.

12. Mattfeld T, Mall G. Statistical methods for growth allometric studies. Growth 1987; 51: 86-102.

13. Austin A, Fagan DG, Mayhew TM. A stereological method for estimating the total number of ventricular myocyte nuclei in fetal postnatal hearts. J Anat 1995; Pt 3: 641-7.

14. Gilbert-Barness E (ed.). Potter's Pathology of the Fetus and Infant. St. Louis: Mosby-Year Book, 1997.

15. Valdés-Dapena M, McFeeley PA, Hoffman HJ, et al. Histopathology Atlas for the Sudden Infant Death Syndrome. Armed Forces Institute of Pathology/American Registry of Pathology/The National Institute of Child Health and Human Development, 1993.

16. Atkinson JB. Pathobiology of sundden death: coronary causes. Cardiovasc Pathol 1994; 3: 105-15.

17. Carvalho PRA. Reanimação cardiopulmonar - um desafio contra a morte prematura. J Pediatria 1998; 74: 173-4.

18. Saffitz JE. Myocyte interconection at gap junctions and the development of anatomic substrates of ventricular arrhythmias. Cardiovasc Pathol 1994; 3: 87-91.

19. Xavier-Vidal R, Madi K. A hipertensão arterial e a hipertrofia cardíaca com ênfase ao uso experimental de bloqueadores da síntese do óxido nítrico: uma breve revisão. Unimar 1997; 19: 593-610.

20. Streeter GL. Weigth, sitting height, head size, foot length and menstrual age of the human embryo. Contribution to embryology. Carnegie Inst Washington 1920; 11: 143-70.

21. O'Rahilly R, Müller F. Development stages in human embryos including a revision of streeter's "horizons" and a survey of the Carnegie Collection. Carnegie Inst Washington, 1987.
22. Mandarim-de-Lacerda CA. Foot length growth related to crown-rump length, gestational age and weight in human staged fresh fetuses. Surg Radiol Anat 1990; 12 : 103-107.

23. Guihard-Costa A-M, Larroche J-C. Fetal Biometry; Growth Charts for Practical Use in Fetopathology and Antenatal Ultrasonography. Paris: S. Karger Medical and Scientific Publishers, 1995.

24. Weibel ER, Elias H. Quantitative Methods in Morphology. Berlin: SpringerVerlag, 1967

25. Sterio DC. The unbiased estimation of number and sizes of arbitrary particles using the didector. J Microsc 1984; 134:127-136.

26. Gundersen HJG, Bendtsen TF, Korbo L, Marcussen N, et al. Some new, simple and efficient stereological methods and their use in pathological research and diagnosis. APMIS 1988a; 96: 379-94.

27. Gundersen HJG, Bagger P, Bendtsen TF, et al. The new stereological tools: disector, fractionator, nucleator, and point sampled intercepts and their use in pathological research and diagnosis. APMIS 1988b; 96: 857-81.

28. Cruz-Orive LM, Weibel ER. Recent stereological methods for cell biology: a brief survey. Am J Physiol 1990; 258: L148-L56.

29. Mayhew TM. The new stereological methods for interpreting functional morphology from slices of cells and organs. Exp Physiol 1991; 76: 639-65.

30. Zar JH. Biostatistical Analysis. London: Prentice-Hall, 1996.

31. Sokal RR, Rohlf FJ. Biometriy. The Principles and Practice of Statistics in Biological Research. New York: WH Freeman, 1995.

32. Weibel ER. Stereological Methods. vol. 1: Practical Methods for Biological Morphometry. New York: Academic Press, 1979

33. Vidal R.Xavier-, Costa-Neves M, Villar VC, Vianna W, Mandarim-de-LacerdaCA Stereology of the myocardium in fetuses: quantitative study of structural changes in the last two trimesters of gestation. Arq Bras Cardiol 1993; 60: 221-4.

34. Mandarim-de-Lacerda CA, Vidal R Xavier-, Le Floch-Prigent P, Laussau JP. Croissance des myocytes du coeur foetal humain. Étude quantitative de la prolifération et hypertrophie des cardiomiocytes. Séance du Vendredi, 24 Mars 1995, de La Societé Anatomique de Paris, France.

35. Xavier-Vidal R, Costa-Neves M, VillarVC, Mandarim-de-Lacerda CA. Allometric growth of the left ventricular myocardium in human fetuses of the second and third trimesters. Biom Res 1994; 5: 29-34.

36. Xavier-Vidal R, Mandarim-de-Lacerda CA. Cardiomyocyte proliferation and hypertrophy in the human fetus: quantitative study of the myocyte nuclei. Bull Assoc Anat 1995; 79:27-31.

37. Xavier-Vidal R. Multivariate analysis of the human heart during fetal development. Biom Res 1996; 7: 49-55.

38. Santos MB dos, Mandarim-de-Lacerda CA. Miocárdio fetal humano. Proliferação do miócito e desenvolvimento do interstício cardíaco nos dois últimos trimestres gestacionais. Arq Bras Cardiol 1997; 68: 99-102.

39. Tosi P, Kraft R, Luzi P, et al. Involution patterns of the cortical area as a function of age. Clin Exp Immunol 1982; 47: 497-504

40. Tosi P. Leoncini L. Morphometry of lymphoid organs in health and disease. Path Res Pract 1984; 179: 209-97.

41. Baak JPA, Oort J. A manual of morphometry in diagnostic pathology. Berlin Heidelberg, Springer-Verlag, 1983.

42. Atkins DL, Rosental JK, Krumm MWJJr. Aplication of stereological analysis of cell volume[nu] to isolated myocytes in culture with and without adrenergic innervation. Anat Rec 1991; 231:209-17.

43. Xavier-Vidal R. Alterações morfológicas do miocárdio devidas a hipertensão arterial induzida por inibidor da síntese do óxido nítrico. Estudo experimental 
em ratos. Niterói, RJ, 1995: 97p. Dissertação (Mestre em Patologia, com área de concentração em Patologia Experimental). Universidade Federal Fluminense.

44. Anversa P, Olivetti G, Loud AV. Morphometric study of early postnatal development in the left and right ventricular myocardium of the rat: I. hypertrophy, hyperplasia, and binucleation of myocytes. Circ Res 1980; 46: 496-502.

45. Zak, R. Cell proliferating during the cardiac growth. Am JCardiol 1973;31:211- 19.

46. Hally, A. Counting method for measuring the volumes of tissue components in microscopical sections. Quarterly J Microsc Sci 1964; 115: 503.

47. Mandarim-de-Lacerda CA. Métodos Quantitativos em Morfologia. Rio de Janeiro: EDUERJ, 1995.

48. Usson Y, Parazza F, Jouk PS. Method for study of thee-dimensional orientation of nuclei of myocardial cells in fetal human heart by means of confocal scaning laser microscopy. J Microsc 1994; 174: 101-10.

49. McGee JO'D, Isaacson PG, Nicholas AW. Oxford Textbook of Patholgy; Pathology of Systems. Oxford: Oxford University Press, 1992.

50. Contran RS, Kumar V, Robbins SL. Robbins: Pathologic Basis of Disease. $5^{\text {th }}$ ed. Philadelphia: WB Saunders, 1994.
51. Hurst JW, Schlant (eds.). The Heart. New York: McGraw-Hill, 1994.

52. Braunwald E (ed). Heart Disease; Textbook of Cardiovascular Medicine. Philadelphia: WB Saunders, 1997.

53. Bugaisky L, Zak R. Biological mechanisms of hypertrophy. In: Fozzard HJ, et al (eds). The Heart and Cardiovascular System. Scientific Foundations. New York: Raven Press, 1986: 1491-506.

54. Weber KT.Cardiac interstitium: extracelular space of the myocardium. In: Fozzard W (ed.). The Heart and Cardiovascular System. $2^{\text {nd }}$ ed. New York: Raven Press, 1992.

55. Tekola P, Zhu Q, Baak JPA. Confocal laser microscopy and processing for threedimensional microscopy: tecnical principles and an application to breast cancer. Human Pathol 1994; 25: 12-21.

56. Gourdie RG, Green CR, Severs NJ. Gapjunction distribution in adult mammalian myocardium revealed by an anti-peptide antibody and laser scanning confocal microscopy. J Cell Science 1991; 99: 41-55.

57. Shiraishi I, Takamatsu T, Fujita S. 3-D Observation of N-cadherin expression during cardiac myofibrillogenesis of the chick embryo using a confocal laser scanning microscope. Anat Embryol 1993; 102: 102-15. 